\author{
Berenika Dyczek \\ Uniwersytet Wrocławski \\ (iD https://orcid.org/0000-0002-1152-8746
}

\title{
Społeczno-kulturowe uwarunkowania postaw tolerancyjnych młodzieży z Cieszyna i Czeskiego Cieszyna (wybrane aspekty)
}

\begin{abstract}
In her article, Berenika Dyczek analyzes the attitudes of high-school students of Polish origin from Cieszyn and Český Těšín towards cultural diversity. Dyczek distinguishes empathic, conformist, active, and passive tolerance and juxtaposes these types with origin, religion, membership in organizations, and linguistic and cultural competence to ask whether there are correlations. She has used quantitative research (a survey with an auditorium questionnaire), which has allowed her to formulate the following conclusions: high cultural and linguistic competences correlate favorably with empathic and active tolerance, while low cultural and linguistic competences correlate with conformist and passive tolerance.
\end{abstract}

Key words: cultural diversity, tolerance, cultural competence

\section{Wstęp}

Badania dotyczące Śląska Cieszyńskiego informują, że mieszkańcy tego regionu posiadają wysoką świadomość tego, czym jest różnorodność kulturowa, narodowa, religijna oraz językowa (Rusek, 2003, s. 9; 2008, s. 87; Chojnacka-Synaszko, 2009, s. 161-169; Lewowicki, Ogrodzka-Mazur, Urban, red., 2009, s. 63-74, 125-138). Oznajmiają też o tym, że różnorodność działa korzystnie na postawy ideowe oraz zachowania prospołeczne ludności na tym terenie. Jednak sam fakt życia na pograniczu kulturowym i językowym nie jest gwarantem pozytywnego wykorzystania zasobów różnorodności. Zbigniew Kurcz twierdzi, że badania nad 
pograniczami wskazują na dwie całkowicie odmienne charakterystyki procesów kulturotwórczych. Z jednej strony, obserwuje się w społecznościach tendencję do otwartej postawy względem innych kultur, z drugiej strony, na niektórych terenach występuje wyjątkowa wrogość do odmiennych kulturowo sąsiadów (Kurcz, 2010, s. 288). Problem ten rozważono w książce Kapitat kulturowy i społeczny młodzieży na Śląsku Cieszyńskim (Dyczek, 2020), w której rozpatrywano m.in. zagadnienie związku różnorodności religijnej z postawami tolerancyjnymi wobec obcych pod względem światopoglądowym oraz związku różnorodności religijnej z kształtowaniem się postaw otwartych w stosunku do wyznawców innych religii.

W tym artykule natomiast skupiono się na pewnym zagadnieniu nie do końca rozwiązanym (wyjaśnionym) w wyżej wymienionej książce, tzn. na genezie współczesnych postaw tolerancyjnych charakteryzujących mieszkańców Śląska Cieszyńskiego oraz podjęto próbę rozstrzygnięcia, jakie czynniki decydują o aktualnym wizerunku zachowań tolerancyjnych $\mathrm{w}$ przypadku młodzieży $\mathrm{z}$ tego regionu. W analizie wzięto pod uwagę takie zmienne jak: różnorodność kulturowa, językowa, religijna, kwestia pochodzenia młodzieży oraz zaangażowanie w działalność organizacji społecznych. Następnie poszukiwano związku między tymi czynnikami a postawami tolerancyjnymi, a także podjęto próbę wyróżnienia składników kulturotwórczych i poddano badaniom te z nich, które na zachowania tolerancyjne mają wpływ pośredni, oraz te, które są ich bezpośrednimi przyczynami.

Materiał empiryczny analizowany w artykule dotyczył młodzieży z Cieszyna oraz Czeskiego Cieszyna. Zebrane informacje umożliwiły wyrażenie poglądu, że wymienione środowiska młodzieżowe są reprezentatywne dla całego Śląska Cieszyńskiego i zastosowano to założenie także w odniesieniu do wyników analiz statystycznych ${ }^{1}$. Przeanalizowano treści zawarte w odpowiedziach respondentów, które wskazywały na to, że młodzież z Czeskiego Cieszyna w większości ma pochodzenie miejscowe i utożsamia się z tradycją Śląska Cieszyńskiego. W przypadku badania postaw tolerancyjnych respondentów zamieszkujących tereny po obu stronach granicy nie zaobserwowano większych różnic statystycznych, co umożliwiło zbiorcze ujęcie ankiet w jednym pakiecie badawczym.

\section{Metodologia badań}

Realizacja badań terenowych nastąpiła między październikiem 2012 a styczniem 2013 roku. Do grupy badawczej należeli uczniowie z liceum, technikum oraz zasadniczej szkoły zawodowej. Rok urodzenia znacznej większości, tzn. 97,4\% uczniów, mieścił się w przedziale 1994-1997. Wielkość próby n = 273 obliczono

${ }^{1}$ W badaniach wzięła udział młodzież ucząca się w gimnazjum z językiem polskim w Czeskim Cieszynie oraz w II Liceum Ogólnokształcącym w Cieszynie. Badania realizowano od października

1442012 do stycznia 2013 roku. 
na podstawie wzoru $\mathrm{n}=\mathrm{N} /\left(\left(1+\mathrm{d}^{2}(\mathrm{~N}-1)\right) / \mathrm{u}_{\alpha}{ }^{2} \mathrm{pq}\right)$, gdzie: $\mathrm{N}$ to liczebność populacji, $\mathrm{p}$ - spodziewany rząd wielkości szacowanej frakcji, $\mathrm{q}=1-\mathrm{p}, \mathrm{u}_{\alpha}$ - to wartość odczytana z tablicy rozkładu $\mathrm{N}(0,1)$ dla przyjętego współczynnika ufności 1- $\alpha$, $\mathrm{d}$ - to dopuszczalny maksymalny błąd szacunku frakcji $\mathrm{p}$ (podawanym w ułamku dziesiętnym) (Greń, 1974, s. 245). Dane zebrano za pomocą kwestionariusza ankiety (sondaż ankietą audytoryjną), wypełnianej przez uczniów podczas zajęć szkolnych. Kwestionariusz zawierał 71 pytań i został podzielony na 4 części. Pierwsza część dotyczyła danych społeczno-ekonomicznych i demograficznych, druga — kompetencji językowych i kulturowych, trzecia — kapitału społecznego, czwarta - kapitału edukacyjnego. Niniejsza praca ogranicza się do analizy tylko kwestii dotyczących relacji między kompetencjami kulturowymi i społecznymi a postawami tolerancyjnymi.

\section{Pochodzenie młodzieży a stosunek do różnorodności kulturowej (typy tolerancji)}

Młodzież z Cieszyna i Czeskiego Cieszyna w badaniach ankietowych została zapytana o to, czy zauważa różnicę między regionem, w którym mieszka, a innymi terytoriami w Polsce. Pytanie to miało na celu zaobserwowanie, czy młodzież jest świadoma odmienności swojego regionu pod względem różnorodności kulturowej oraz czy ocenia tę różnorodność jako coś pozytywnego. Czy nabyty kapitał kulturowy stanowi wartość, z której zalet można korzystać, czy też raczej jest pretekstem skłaniającym do niechęci, konfliktów i agresji?

W badaniach wzięto też pod uwagę niesymetryczność warunków, jakie dotyczą życia w mieście podzielonym pod względem państwowym. Młodzież licealna pochodzenia polskiego z Czeskiego Cieszyna miała program nauczania obowiązujący w Republice Czeskiej i dodatkowo zajęcia z języka polskiego i kultury polskiej, więc dysproporcje w nauce szkolnej pobieranej w szkołach czeskich i polskich są oczywiste. W Czechach nauka religii nie obowiązuje w szkołach państwowych, co mogło wpływać na różnice światopoglądowe. Rozpatrując powyższe kontrowersje, zauważono, że nie kolidują one z poglądem o podobnych kompetencjach kulturowych młodzieży licealnej z Cieszyna i Czeskiego Cieszyna. Na podobne zależności zwróciła uwagę Aniela Różańska analizując tożsamość młodzieży z pogranicza polsko-czeskiego (Różańska, 2010).

${ }^{2} \mathrm{~W}$ badanej grupie wystąpiła nadreprezentacja kobiet $(66,2 \%)$ w stosunku do mężczyzn (33,8\%), jednak płeć nie różnicowała odpowiedzi, dlatego pominięto ją w analizach. 
Tabela 1

Pochodzenie ze Śląska Cieszyńskiego a jego odmienność

\begin{tabular}{|l|c|c|}
\hline \multirow{2}{*}{$\begin{array}{c}\text { Pytanie z ankiety: Jak Ci się wydaje, } \\
\text { czy Śląsk Cieszyński różni się od } \\
\text { innych regionów w Polsce? }\end{array}$} & \multicolumn{2}{|c|}{$\begin{array}{c}\text { Respondenci zamieszkujący [\%] } \\
(N=255)\end{array}$} \\
\cline { 2 - 3 } & Cieszyn & Czeski Cieszyn \\
\hline Tak & 68,9 & 69,9 \\
\hline Nie & 30,9 & 30,1 \\
\hline Ogółem & 100,0 & 100,0 \\
\hline
\end{tabular}

Źródło: badania własne.

Treści odpowiedzi zawartych w przeprowadzonych kwestionariuszach ankiet okazały się podobne dla respondentów z dwóch stron granicy, ponieważ ok. 70\% uczniów zauważa odrębność Śląska Cieszyńskiego i Cieszyna jako miasta podzielonego, w którym mieszka (tabela 1). Dane wskazują na fakt, że młodzież jest świadoma tego, że mieszka na terytorium zróżnicowanym kulturowo. Zmienna terytorialna (Cieszyn Czeski, Cieszyn) nie różnicowała odpowiedzi. Zdiagnozowano natomiast, że większe znaczenie, związane ze świadomością życia na obszarze pogranicza i jego ,inności” od centrum, miała zmienna określająca pochodzenie (ze Śląska Cieszyńskiego lub nie). Inaczej mówiąc, większą wagę miało pochodzenie ze Śląska Cieszyńskiego niż aktualne miejsce zamieszkania, tzn. Czechy lub Polska. Około 90\% młodzieży zadeklarowało pochodzenie ze Śląska Cieszyńskiego ale wśród pozostałych $10 \%$, które pochodziło $\mathrm{z}$ innych regionów, dostrzeżono uproszczoną schematyczną świadomość problematyki kulturowej pogranicza oraz odmienne postawy w stosunku do różnorodności. Dlatego uznano, że warto bliżej przyjrzeć się tym kwestiom, gdyż większość mieszkańców Śląska Cieszyńskiego jest ludnością tutejszą, silnie związaną z tradycją historyczną Księstwa Cieszyńskiego 4 .

Warto zwrócić uwagę na fakt, że zmienna informująca o pochodzeniu ze Śląska Cieszyńskiego, w porównaniu ze zmienną informującą o pochodzeniu z innych regionów Polski, znacznie kontrastuje odpowiedzi. Około 70\% młodzieży ze Śląska Cieszyńskiego zauważała odmienność Cieszyna, natomiast młodzież z innych regionów Polski nie dostrzegała specyfiki miasta w tak znaczącym stopniu, bo tylko około $50 \%$ respondentów dostrzegało różnice (tabela 2).

Tabela 2

Pochodzenie ze Śląska Cieszyńskiego a odmienność Cieszyna

\begin{tabular}{|c|c|c|c|}
\hline \multirow{6}{*}{ 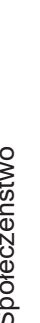 } & \multirow{2}{*}{$\begin{array}{l}\text { Pytanie z ankiety: Jak Ci się wydaje, } \\
\text { czy Cieszyn różni się od miast } \\
\text { podobnej wielkości w Polsce? }\end{array}$} & \multicolumn{2}{|c|}{$\begin{array}{l}\text { Pochodzenie respondentów [\%] } \\
\qquad(N=255)\end{array}$} \\
\hline & & Śląsk Cieszyński & Inny region \\
\hline & Tak & 70,3 & 53,3 \\
\hline & $\mathrm{Nie}$ & 29,7 & 46,7 \\
\hline & Ogółem & 100,0 & 100,0 \\
\hline & \multicolumn{3}{|l|}{ Źródło: badania własne. } \\
\hline
\end{tabular}


Tabela 3 ukazuje, w jaki sposób młodzież uzasadniła swoją opinię o tym, że Cieszyn różni się od innych miast w Polsce o podobnej wielkości. Pytanie to miało na celu zaobserwowanie tego, w jaki sposób młodzież zdefiniowała odmienność Cieszyna. Na podstawie odpowiedzi respondentów można było ustalić, jaki jest ich poziom świadomości, czy nawet kompetencji, w kwestii różnorodności kulturowej.

Pochodzenie ze Śląska Cieszyńskiego a specyfika Cieszyna w opinii młodzieży

\begin{tabular}{|l|c|c|}
\hline \multirow{2}{*}{$\begin{array}{c}\text { Pytanie z ankiety: } \\
\text { Dlaczego Cieszyn różni się od innych miast? }\end{array}$} & \multicolumn{2}{|c|}{$\begin{array}{c}\text { Pochodzenie respondentów [\%] } \\
(N=184)\end{array}$} \\
\cline { 2 - 3 } & Śląsk Cieszyński & Inne regiony \\
\hline Różnorodność kulturowa & 68,4 & 48,0 \\
\hline Działalność organizacyjna & 4,1 & 16,0 \\
\hline Czynniki subiektywne & 13,3 & 20,0 \\
\hline Cechy przestrzenne & 12,2 & 9,0 \\
\hline Brak akceptacji & 2,0 & 5,0 \\
\hline Ogółem & 100,0 & 100,0 \\
\hline
\end{tabular}

Źródło: badania własne.

W tabelach 3 i 4 rozważano kategorie, które mogłyby posłużyć wyodrębnieniu widocznych różnic w odniesieniu do subiektywnych i obiektywnych spostrzeżeń respondentów, dotyczących środowiska, w którym funkcjonują. Okazuje się, że prawie 70\% młodzieży pochodzącej ze Śląska Cieszyńskiego definiuje Cieszyn jako miasto różnorodne pod względem kulturowym, językowym, religijnym i narodowym. Młodzież pochodząca z innych regionów, a ucząca się i mieszkająca w Cieszynie, na różnorodność tę zwracała uwagę rzadziej (48\%). Dość duży odsetek odpowiedzi otrzymały kwestie związane z działalnością w środowiskowych organizacjach społecznych Cieszyna oraz kwestie subiektywne, czyli takie, które nie do końca zostały zracjonalizowane, np. wyjątkowa atmosfera czy magia tego miejsca. Dane w tabelach 3 i 4 wyraźnie wskazują na związek między pochodzeniem młodzieży ze Śląska Cieszyńskiego a świadomością różnorodności, która prawdopodobnie wynika z socjalizacji odbywającej się na pograniczu różnych kultur.

Kategorie w tabeli 4 zostały utworzone na podstawie otwartych wypowiedzi respondentów. W celu bliższego zobrazowania charakteru treści zawartych w ankietach wybrano przykładowe odpowiedzi, należące do poszczególnych kategorii. Ujęte zostały najbardziej typowe stwierdzenia, zrezygnowano z powtarzających się wypowiedzi. 
Charakterystyka Cieszyna jako miasta

\begin{tabular}{|c|c|}
\hline Kategoria opisu & Wypowiedzi respondentów* \\
\hline $\begin{array}{l}\text { 1. Różnorodność } \\
\text { kulturowa (językowa, } \\
\text { religijna, narodowa } \\
\text { itp.) }\end{array}$ & $\begin{array}{l}\text { - Różnorodność religijna, dużo ludzi z innych miast. } \\
\text { - Więcej ewangelików. } \\
\text { - Jest mieszanka religijna, dostęp do Czech, a co za tym idzie przenika- } \\
\text { nie się narodowości i języka. } \\
\text { - Różni się narodowością i wyznaniem. } \\
\text { - Strefa wpływów czeskich i polskich. Dwujęzyczność. } \\
\text { - Bogata historia. Nigdy nie był pod okupacją, blisko granicy czeskiej. } \\
\text { Inna mentalność ludzi uwarunkowana przeszłością. } \\
\text { - Wielokulturowość. Na każdym kroku słyszy się polski i czeski język, } \\
\text { gwara. } \\
\text { - Inaczej postrzega obcokrajowców, widać wpływ czeskiej ludności, } \\
\text { - jest sporo imprez integracyjnych. } \\
\text { - Ponieważ mamy tu inną kulturę. } \\
\text { - Jest tu wiele osób różnego wyznania, jest tu specyficzny klimat. } \\
\text { - Różni się uwarunkowaniami kulturalnymi. } \\
\text { - Na terytorium Śląska Cieszyńskiego jest mnóstwo grup etnicznych, } \\
\text { - Jest najodowych i kulturowych. }\end{array}$ \\
\hline $\begin{array}{l}\text { 2. Działalność } \\
\text { organizacyjna }\end{array}$ & $\begin{array}{l}\text { - Jest małym miastem, a mimo to dużo jest tu obiektów kulturalnych } \\
\text { dla ludzi. } \\
\text { - Jest to bardzo ładne miejsce, gdzie są organizowane różne spotkania. } \\
\text { - Instytucje kultury. } \\
\text { - Dużo zabytków, atrakcyjne kluby sportowe. }\end{array}$ \\
\hline $\begin{array}{l}\text { 3. Czynniki } \\
\text { subiektywne (coś ma } \\
\text { w sobie itp.), styl } \\
\text { życia }\end{array}$ & $\begin{array}{l}\text { - Żyje się tu specyficznie. Ma klimat starego miasteczka. } \\
\text { - Jest mały, bardzo przytulny i ma w sobie wdzięk. } \\
\text { - Ponieważ w tym mieście jest specyficznie... oraz ludzie mają inne } \\
\text { podejście do siebie. } \\
\text { - Ma swój własny charakter. } \\
\text { - Różni się sposobem bycia. } \\
\text { - Dla mnie Cieszyn ma coś w sobie, wyjątkowe, piękne miasto. } \\
\text { - Cieszyn jest bardziej specyficzny. }\end{array}$ \\
\hline $\begin{array}{l}\text { 4. Cechy przestrzenne } \\
\text { (blisko/daleko), } \\
\text { architektura }\end{array}$ & $\begin{array}{l}\text { - Ukształtowanie terenu, kultura, przyroda. } \\
\text { - Znajduje się blisko nas. } \\
\text { - Atrakcyjny, ładne widoki — każde miasto poniekąd różni się wieloma } \\
\text { czynnikami, styl budownictwa. } \\
\text { - Inna architektura. }\end{array}$ \\
\hline 5. Brak akceptacji & $\begin{array}{l}\text { - Ludzie są niemili wobec tych, którzy nie pochodzą stela [w gwarze } \\
\text { cieszyńskiej — być stąd], są wredni, chamscy, aroganccy, przy tym } \\
\text { mało wykształceni. }\end{array}$ \\
\hline
\end{tabular}

Kolejna kwestia dotyczy tolerancji na poziomie praktycznym. Czyli informacji o konkretnych zachowaniach respondentów, gdy stykają się na co dzień z ludźmi, 148 którzy są reprezentantami odmiennych kultur. Okazuje się, że ponad 80\% młodzie- 
ży, niezależenie od miejsca zamieszkania, w Polsce czy w Czechach, nie dostrzega faktu, że obok nich żyją ludzie z różnych środowisk kulturowych (tabela 5).

Tabela 5

Pochodzenie ze Śląska Cieszyńskiego a dostrzeganie odmienności

\begin{tabular}{|l|c|c|}
\hline \multirow{2}{*}{$\begin{array}{c}\text { Pytanie z ankiety: } \\
\text { Czy spotykasz osoby, które inaczej } \\
\text { myślą i inaczej się zachowują? }\end{array}$} & \multicolumn{2}{|c|}{$\begin{array}{c}\text { Pochodzenie respondentów [\%] } \\
(N=260)\end{array}$} \\
\cline { 2 - 3 } & Cieszyn & Czeski Cieszyn \\
\hline Tak & 82,3 & 85,4 \\
\hline Nie & 17,7 & 14,6 \\
\hline Ogółem & 100,0 & 100,0 \\
\hline
\end{tabular}

Źródło: badania własne.

Z badawczego punktu widzenia ważny jest sposób reakcji podmiotu na kontakty z ludźmi reprezentującymi kulturowo odmienne systemy wartości. Należy tu uwzględnić istnienie relacji między konkretnymi postawami względem odmienności kulturowej a innymi zmiennymi. Podobnie jak w poprzednim pytaniu, okazało się, że najsilniejszy wpływ na typ reakcji ma czynnik związany z pochodzeniem, i co za tym idzie - tradycja Śląska Cieszyńskiego (tabela 6). Nie zaobserwowano, by miejsce zamieszkania powodowało nadmierne zainteresowanie tematyką religijną. Nie wykryto większych różnic w odpowiedziach młodzieży, która była wyznania katolickiego lub ewangelickiego.

Tabela 6

Pochodzenie respondentów a stosunek do różnorodności kulturowej

(typy tolerancji)

\begin{tabular}{|l|c|c|}
\hline \multirow{2}{*}{\multicolumn{1}{|c|}{ Typy tolerancji }} & \multicolumn{2}{c|}{$\begin{array}{c}\text { Pochodzenie respondentów [\%] } \\
(N=184)\end{array}$} \\
\cline { 2 - 3 } & Śląsk Cieszyński & Inne regiony \\
\hline Empatyczna & 26,4 & 5,0 \\
\hline Konformistyczna & 14,4 & 22,8 \\
\hline Aktywna & 10,3 & 8,0 \\
\hline Pasywna & 47,1 & 47,8 \\
\hline Brak tolerancji & 1,8 & 16,4 \\
\hline Ogółem & 100,0 & 100,0 \\
\hline
\end{tabular}

Źródło: badania własne.

Do tabeli 6 wprowadzono cztery kategorie, będące pomysłem autorskim, które objaśniają podejścia respondentów do sposobu wyrażania lub rozumienia tolerancji. Empatyczna tolerancja to rozumienie ,innego" zgodne z jego definicją tolerancji. Konformistyczna tolerancja oznacza takie jej rozumienie, które odpowiada obiegowym, ogólnie przyjętym sądom na ten temat. Aktywna tolerancja polega na wcielaniu w życie jej zasad. Pasywna tolerancja odnosi się do biernej akceptacji jej zasad, przejawiając się brakiem zaangażowania społecznego. 
Postawy wobec różnorodności zostały zaklasyfikowane zgodnie z treścią odpowiedzi respondentów zawartych w ankietach. Dokonano konfrontacji poglądów respondentów wyrażających empatyczną tolerancję vs konformistyczną tolerancję oraz aktywną tolerancję vs pasywną tolerancję. W tabeli 7 przedstawiono przykładowe, reprezentatywne dla poszczególnych kategorii odpowiedzi z pominięciem powtarzających się lub bardzo podobnych.

Zdecydowaną różnicę $\mathrm{w}$ wyrażonych opiniach na temat tolerancji można zaobserwować w przypadku tolerancji empatycznej, ponieważ ok. $26 \%$ młodzieży wykazało taką postawę, przy 5\% uczniów pochodzących z innych regionów Polski. Należy pamiętać, że z innych obszarów Polski pochodziło tylko ok. 10\% uczniów i procenty odnoszą się do tej grupy. Możemy tutaj zaobserwować jakościowo odmienne postawy. Tak duże rozbieżności w przekonaniach obu grup (10\% respondentów pochodzących spoza Cieszyna i Śląska Cieszyńskiego i 90\% pochodzących $\mathrm{z}$ tego regionu) są znamienne, więc warto te różnice przeanalizować. Tym bardziej, że dysproporcja ta charakteryzuje całą populację młodzieży z Cieszyna i Czeskiego Cieszyna w porównaniu z młodzieżą pochodzącą z innych regionów Polski.

Watro zauważyć, że empatyczna tolerancja $\mathrm{w}$ sumie $\mathrm{z}$ aktywną tolerancją osiągnęła poziom $40 \%$ wśród młodzieży pochodzącej ze Śląska Cieszyńskiego, a 13\% wśród uczniów pochodzących z innych regionów Polski.

Tabela 7

Postawy tolerancji

\begin{tabular}{|c|c|}
\hline Typy tolerancji & Wypowiedzi respondentów* \\
\hline $\begin{array}{l}\text { 1. Empatyczna } \\
\text { tolerancja (ze } \\
\text { współczynnikiem } \\
\text { humanistycznym)- } \\
\text { staram się zrozumieć }\end{array}$ & $\begin{array}{l}\text { - Staram się te osoby rozumieć, imponują mi. } \\
\text { - Słucham ich zdania, a potem wypowiadam się o ich przekonaniach. } \\
\text { - Toleruję ich, każdy decyduje za siebie. } \\
\text { - Wiem, że każdy jest inny, i nie chcę nikogo przekonywać o mojej racji. } \\
\text { - Normalnie każdy jest oryginalny i trzeba go szanować. } \\
\text { - Uważam, że każdy ma prawo do własnego zdania, jeżeli tylko wyraża } \\
\text { je w sposób kulturalny. } \\
\text { - Jestem tolerancyjna, nie przeszkadza mi to, uważam, że każdy powi- } \\
\text { nien mieć swoje poglądy. } \\
\text { - Każdy był wychowany inaczej, akceptuję to. Patrzę i uczę się. } \\
\text { - Każdy ma swoje zdanie i prawo do własnych przekonań. } \\
\text { - Ze zrozumieniem, akceptuję. } \\
\text { - Uważam, że odmienność, dziwactwo trzeba ukrywać, bo w tym } \\
\text { świecie od razu zostaniemy zaatakowani. Trzeba to zrozumieć. } \\
\text { - Szanuję ich zdanie, mimo że go nie podzielam. } \\
\text { - Staram się ich zrozumieć i wymieniam się z nimi swoimi opiniami. }\end{array}$ \\
\hline $\begin{array}{l}\text { 2. Konformistyczna } \\
\text { tolerancja - toleruję, } \\
\text { bo inni mają prawo } \\
\text { do odmienności }\end{array}$ & $\begin{array}{l}\text { - Toleruję ich, lecz nie zawsze się z nimi zgadzam, ale mają do tego prawo. } \\
\text { - Póki mnie nie ograniczają i nie szkodzą, to toleruję. } \\
\text { - Toleruję to. } \\
\text { - Cóż mogę na to poradzić, każdy ma prawo myśleć inaczej niż ja, nie } \\
\text { reaguję na to, bo nie ma sensu, człowieka się nie zmieni. } \\
\text { - Toleruję, jeśli bardzo mi to przeszkadza, to staram się izolować. } \\
\text { - Przeważnie w ogóle nie reaguję, ale drażni mnie to. } \\
\text { - Szanuję zdanie innych, ale się z nim nie utożsamiam. }\end{array}$ \\
\hline
\end{tabular}


cd. tab. 7

\begin{tabular}{|c|c|}
\hline $\begin{array}{l}\text { 3. Aktywna tolerancja } \\
\text { - toleruję, ale } \\
\text { wyrażam swoje } \\
\text { zdanie, jeśli coś } \\
\text { mi się nie podoba; } \\
\text { przedstawiam } \\
\text { własne poglądy } \\
\text { i uzasadniam swoje } \\
\text { przekonania, } \\
\text { czasem dyskutuję } \\
\text { w tej kwestii; jestem } \\
\text { tolerancyjna/y, ale } \\
\text { mam swoje zdanie }\end{array}$ & $\begin{array}{l}\text { - Przedstawiam im moje poglądy i uzasadniam swoje przekonania, } \\
\text { czasem dyskutuję w tej kwestii. } \\
\text { - Zależy, o co chodzi, czasami wytykam, a czasami nie interweniuję. } \\
\text { - Zależy, w jakim stopniu to mnie drażni - zwracam im uwagę lub } \\
\text { wcale nie reaguję. } \\
\text { - Akceptuję ich zachowanie, ale nie odstępuję od swoich racji. } \\
\text { - Czasami mówię im to, co mi się nie podoba w ich rozmowach. } \\
\text { - Jestem tolerancyjna, ale mam swoje zdanie, sprzeczam się z nimi, } \\
\text { rozmawiam z nimi, szanuję ich odrębność. } \\
\text { - Mówię im, że są ignorantami i brak im szacunku dla swoich przodków. } \\
\text { - Czasem oburzeniem, a czasem toleruję. } \\
\text { - Zależy, czy takie zachowanie mnie denerwuje, czy nie, wymieniam } \\
\text { poglądy. }\end{array}$ \\
\hline $\begin{array}{l}\text { 4. Pasywna tolerancja } \\
\text { — zachowuję się } \\
\text { obojętnie, normalnie, } \\
\text { ignoruję, akceptuję }\end{array}$ & $\begin{array}{l}\text { - Toleruję to, ale nie zwracam na wszystko wielkiej uwagi. } \\
\text { - Akceptuję, lecz czasami mnie to irytuje. } \\
\text { - Akceptuję to, nijak. } \\
\text { - Nie zwracam na to uwagi. Nie interesuje mnie to. } \\
\text { - Nie mam konkretnego sposobu. } \\
\text { - Nie reaguję, jest to OK. } \\
\text { - Nie reaguję, oni są sobą, ja jestem sobą, a dopóki nie ingerują we mnie } \\
\text { i moją osobę, nie obchodzi mnie to. } \\
\text { - Nie rusza mnie to, dopóki nie zamieni się w działanie. } \\
\text { - Nie interesuje mnie to, jest mi to obojętne. Ignoruję. } \\
\text { - Nie reaguję w żaden sposób. } \\
\text { - Ignorancją, uśmiechem. Ignoruję to, chyba, że osoba jest mi bliska. } \\
\text { - Normalnie, nie interesuje mnie myślenie innych osób. } \\
\text { - Nie rozmawiam z nimi. } \\
\text { - Jeżeli nie jest to krzywdzące dla mnie, nie obchodzi to mnie. }\end{array}$ \\
\hline $\begin{array}{l}\text { 5. Dyskryminacja - } \\
\text { nie toleruję }\end{array}$ & $\begin{array}{l}\text { - Jeżeli mi kolega/koleżanka powie, że jest Czechem, jestem bardzo } \\
\text { zdenerwowany. }\end{array}$ \\
\hline
\end{tabular}

* Nie wyszczególniono odpowiedzi podobnych lub powtarzających się

Źródło: badania własne.

\section{Różnorodność religijna a postawy tolerancyjne młodzieży}

Różnorodność religijna jest jednym $\mathrm{z}$ aspektów różnorodności kulturowej. Badacze Śląska Cieszyńskiego zauważają, że jest to wyjątkowy obszar ze względu na zamieszkujących tu ewangelików. W tym regionie mamy największe skupisko luteran, jeśli chodzi o terytorium Polski, a diecezja cieszyńska liczy 45000 wyznawców (Lewowicki et al., red., 2002, s. 267). Z tego powodu śledzenie związku między wyznaniem a świadomością różnorodności oraz postawami 
tolerancyjnymi wydaje się ważnym postulatem badawczym. Różnorodność religijna jest więc jednym z czynników, który umożliwia realizację kanonów edukacji międzykulturowej w praktyce. Jerzy Nikitorowicz podaje, że edukacja międzykulturowa to „ogół wzajemnych wpływów i oddziaływań jednostek i grup, instytucji, organizacji, stowarzyszeń, związków, sprzyjających takiemu rozwojowi człowieka, aby stawał się on w pełni świadomym i twórczym członkiem wspólnoty rodzinnej, lokalnej, regionalnej, wyznaniowej, narodowej, kontynentalnej, kulturowej, globalnej — planetarnej oraz był zdolny do aktywnej samorealizacji własnej, niepowtarzalnej i trwałej tożsamości i odrębności” (Lewowicki et al., red., 2003, s. 44-45). A konsekwencją takiego stanowiska jest ,przezwyciężenie tendencji do zamykania się w sferze własnych wartości, własnego kręgu kulturowego na rzecz otwarcia i zrozumienia innych, poszanowania dla różnic i traktowania ich, jako czynnika rozwojowego" (Lewowicki et al., red., 2003, s. 44).

Tabela 8

Wyznanie a dostrzeganie specyfiki kulturowej Cieszyna

\begin{tabular}{|l|c|c|c|c|}
\hline \multirow{2}{*}{$\begin{array}{c}\text { Dostrzeganie specyfiki kulturowej } \\
\text { Cieszyna }\end{array}$} & \multicolumn{4}{|c|}{$\begin{array}{c}\text { Wyznanie respondentów [\%] } \\
(N=124)\end{array}$} \\
\cline { 2 - 5 } & katolickie & ewangelickie & inne & bezwyznaniowy \\
\hline Różnorodność kulturowa & 69,0 & 67,9 & 73,0 & 61,5 \\
\hline Działalność organizacyjna & 3,4 & 7,1 & 1,0 & 7,7 \\
\hline Czynniki subiektywne & 13,8 & 14,3 & 1,0 & 15,4 \\
\hline Cechy przestrzenne & 10,3 & 10,7 & 25,0 & 15,4 \\
\hline Brak akceptacji & 3,5 & 0,0 & 0,0 & 0,0 \\
\hline Ogółem & 100,0 & 100,0 & 100,0 & 100,0 \\
\hline
\end{tabular}

Źródło: badania własne.

Tabela 9

Wyznanie a typy tolerancji młodzieży

\begin{tabular}{|c|c|c|c|c|}
\hline \multirow[t]{2}{*}{ Typy tolerancji } & \multicolumn{4}{|c|}{$\begin{array}{l}\text { Wyznanie respondentów [\%] } \\
\qquad(N=181)\end{array}$} \\
\hline & katolickie & ewangelickie & inne & bezwyznaniowy \\
\hline Empatyczna & 27,7 & 22,4 & 23,5 & 16,7 \\
\hline Konformistyczna & 8,9 & 22,4 & 5,9 & 16,7 \\
\hline Aktywna & 9,9 & 8,3 & 41,2 & 11,1 \\
\hline Pasywna & 53,5 & 46,9 & 29,4 & 55,4 \\
\hline Ogółem & 100,0 & 100,0 & 100,0 & 100,0 \\
\hline
\end{tabular}

Źródło: badania własne.

Wydaje się, że odpowiedzi w tabelach 8 i 9 wskazują na brak koincydencji między wyznaniem a dostrzeganiem i rozumieniem różnorodności oraz postawami tolerancyjnymi. Około $70 \%$ młodzieży wyznania katolickiego oraz około 
68\% młodzieży wyznania ewangelickiego deklaruje, że jest świadoma odrębności kulturowej Cieszyna. Podobnie jest w przypadku postaw tolerancyjnych. Empatyczna i aktywna tolerancja nie zależy od wyznania. Analiza odpowiedzi wskazuje raczej na fakt, że różnorodność religijna stanowi czynnik pośredni, wpływający na świadomość odmienności tego regionu oraz postawy tolerancyjne. Należy przypuszczać również, że style życia młodzieży wyznania ewangelickiego oraz katolickiego wpływają wzajemnie na postawy młodzieży i w związku z tym trudna do wychwycenia empirycznego jest dominująca pozycja jednego z wyznań. Na obraz tolerancji składają się też liczne małżeństwa mieszane, w których nie łatwo doszukać się przewagi określonej religii. Praktyki i obrzędy religijne wzmacniają jakość relacji międzyludzkich. Pisze o tym Wojciech Świątkiewicz w dysertacji Rola religijności w procesach legitymizacji społecznego świata (Świątkiewicz, 1993, s. 37).

\section{Zaangażowanie w działalność organizacji społecznych a postawy tolerancyjne młodzieży}

Kolejne pytanie, uwzględniające aspekt światopoglądowy, otwierało drogę do wydobycia informacji o tym, czy świadomość różnorodności i postaw tolerancyjnych ma wpływ na działalność organizacyjną, która jest jednym z kluczowych budulców kapitału społecznego ${ }^{5}$. W kontekście postaw tolerancyjnych warto również wspomnieć o kapitale pomostowym oraz spajającym według Roberta D. Putnama (2008). Ten pierwszy występuje wtedy, gdy integruje środowiska o różnych cechach i pojawia się właśnie przy działalności organizacji pozarządowych, natomiast kapitał spajający dotyczy zamkniętych środowisk, do których obcy nie mają wstępu. Na Śląsku Cieszyńskim możemy zaobserwować większą rolę tego pierwszego, co przekłada się na istnienie wysokiej korelacji między członkostwem w stowarzyszeniach a rzeczywistą działalnością. W uproszczeniu możemy uznać, że deklarowane członkostwo w organizacjach jest tożsame z faktyczną działalnością stowarzyszeniową (Dyczek, 2020, s. 200-202).

Młodzież z Cieszyna i Czeskiego Cieszyna, która zadeklarowała członkostwo w organizacjach, częściej zauważa różnorodność kulturową swojego miasta (76,9\%) w porównaniu z młodzieżą niezaangażowaną w działalność społeczną (49,6\%). Młodzież niezaangażowana społecznie z kolei, nastawiona do rzeczywistości refleksyjnie, częściej kierowała uwagę na czynniki subiektywne, wyrażające się w klimacie miasta, zaletach architektury, przyjaznej atmosferze, będącej zasługą jego mieszkańców (tabela 9).

Treść odpowiedzi respondentów zawarta $\mathrm{w}$ tabeli 10 informuje, że nie ma większych dysproporcji statystycznych ze względu na społeczną działalność orga-

\footnotetext{
${ }^{5}$ Szerzej o kapitale społecznym zob. Dyczek, 2020.
} 
nizacyjną lub jej brak w stosunku do postaw tolerancyjnych. W analizowanym przypadku występuje podobny rozkład odpowiedzi respondentów działających w organizacjach lub niezaangażowanych społecznie.

Członkostwo w organizacjach a dostrzeganie specyfiki kulturowej Cieszyna

\begin{tabular}{|c|c|c|}
\hline \multirow{2}{*}{$\begin{array}{c}\text { Dostrzeganie specyfiki kulturowej } \\
\text { Cieszyna }\end{array}$} & \multicolumn{2}{|c|}{$\begin{array}{l}\text { Członkostwo respondentów w organizacjach [\%] } \\
\qquad(N=121)\end{array}$} \\
\hline & Tak & Nie \\
\hline Różnorodność kulturowa & 76,9 & 49,6 \\
\hline Działalność organizacyjna & 10,0 & 9,6 \\
\hline Czynniki subiektywne & 3,5 & 16,5 \\
\hline Cechy przestrzenne & 5,8 & 20,3 \\
\hline Brak akceptacji & 3,8 & 4,0 \\
\hline Ogółem & 100,0 & 100,0 \\
\hline
\end{tabular}

Źródło: badania własne.

Tabela 10

Członkostwo w organizacjach a stosunek do różnorodności

\begin{tabular}{|l|c|c|}
\hline \multirow{2}{*}{\multicolumn{1}{c}{ Typy tolerancji }} & \multicolumn{2}{c|}{$\begin{array}{c}\text { Członkostwo respondentów w organizacjach [\%] } \\
(N=182)\end{array}$} \\
\cline { 2 - 3 } & Tak & Nie \\
\hline Empatyczna & 33,0 & 31,5 \\
\hline Konformistyczna & 18,0 & 13,2 \\
\hline Aktywna & 9,9 & 7,8 \\
\hline Pasywna & 39,1 & 45,5 \\
\hline Brak tolerancji & 0,0 & 2,0 \\
\hline Ogółem & 100,0 & 100,0 \\
\hline
\end{tabular}

Źródło: badania własne.

Członkostwo w organizacjach społecznych nie decyduje w arbitralny sposób o postawach i zachowaniach młodzieży szkolnej wobec tych, którzy prezentują odmienne poglądy i wartości. Wpływa natomiast na samą świadomość i rozumienie różnorodności, co wydaje się logiczne, gdyż młodzież działająca w organizacjach ma możliwość wzmożonego obcowania z ,innymi” i obserwacji ich zachowań, a także wchodzenia $\mathrm{w}$ relacje bezpośrednie. Osobiste kontakty i bezpośrednia komunikacja z osobami wyznającymi inne wartości oraz prezentujące różne kultury pogłębia wiedzę o świecie i sprzyja tolerancji. 


\section{Kompetencje kulturowe i językowe a tolerancja młodzieży}

Analiza danych statystycznych umożliwiła wyodrębnienie zależności między pochodzeniem respondentów ze Śląska Cieszyńskiego a postawami tolerancyjnymi. Poszukiwanie i wykrycie konkretnych czynników, za którymi kryje się ta zależność, umożliwiło postawienie hipotezy, że jest to właśnie oddziaływanie kompetencji językowych i ogólnie kulturowych, ponieważ młodzież ze Śląska Cieszyńskiego cechuje się właśnie wysokim kapitałem kulturowym oraz społecznym ${ }^{6}$.

W ramach kompetencji językowych wykorzystano model kodów językowych Bernsteina (kod rozbudowany i ograniczony) oraz wskaźniki Hola (1998), takie jak: estetyka formalna; czynniki praktyczne/indywidualistyczne; sprawozdawczy krytyczny odbiór kultury (określenia konkretne/abstrakcyjne); samorealizacja - postawa twórcza. Natomiast do zdefiniowania kompetencji kulturowych w wymiarze praktycznym (dotyczącym wartości) wykorzystano aspekty ucieleśnionego kapitału kulturowego według Bourdieu. Respondenci zostali poproszeni o podanie ulubionych artystów $\mathrm{z}$ takich dziedzin jak literatura, muzyka, malarstwo i rzeźba oraz film oraz o uzasadnienie swojego wyboru. Następnie na podstawie odpowiedzi zostały stworzone wskaźniki ilościowe ${ }^{7}$ (Bourdieu, 2005). Tabele 11 i 12 informują, jak kompetencje językowe wpływają na świadomość różnorodności kulturowej oraz postawy tolerancyjne. Natomiast tabele 13 i 14 przedstawiają związek kompetencji językowych ze świadomością różnorodności kulturowej oraz postawami tolerancyjnymi. Można dostrzec, że odsetek odpowiedzi odnoszących się do różnorodności kulturowej wyraźnie rośnie wraz ze wzrostem kompetencji językowych. Różnorodność kulturowa jest główną właściwością, która odróżnia Cieszyn od innych miast Polski. Informację taką podało 37,4\% respondentów posiadających wysokie kompetencje językowe, 21,3\% młodzieży o średnich kompetencjach językowych oraz tylko 3,3\% o niskich. Podobną zależność możemy zaobserwować w przypadku postaw tolerancyjnych. Wskaźniki empatycznej tolerancji rosną wraz ze wzrostem kompetencji językowych (53\% respondentów z wysokimi kompetencjami językowymi, 42,8\% ze średnimi, a 15,5\% z niskimi).

Współegzystencja wysokich kompetencji językowych z tolerancją empatyczną oraz wiedzą o różnorodności kulturowej pozwalają postawić tezę o istnieniu związku między tymi czynnikami a poziomem akceptacji różnorodności kulturowej.

Respondenci z niskimi wskaźnikami kompetencji kulturowej i językowej dużo rzadziej zauważali różnorodność kulturową w Cieszynie jako czynnik wyróżniający to miasto i również rzadziej określali swoją postawę jako empatyczną tolerancję w porównaniu z młodzieżą ze średnim i wysokim kapitałem. Zdecydowana większość młodzieży uważa, że różnorodność kulturowa jest główną cechą miasta Cieszyna, ale osoby z niskimi kompetencjami kulturowymi preferowały inne

\footnotetext{
${ }^{6}$ Rozdział historyczny zob. Dyczek, 2020.

${ }^{7}$ Omówienie konceptualizacji znajduje się w: Dyczek, 2020, s. 134—137, 153-184.
} 
odpowiedzi, takie jak działalność organizacyjna (32,0\%), czynniki subiektywne czy cechy przestrzenne $(24,9 \%)$. Wskaźniki tolerancji empatycznej również są wyższe u młodzieży posiadającej wysokie $(53,1 \%)$, i średnie kompetencje kulturowe $(47,8 \%)$, natomiast niskie wskaźniki dotyczą 15,5\% respondentów.

Tabela 11

Kompetencje językowe a dostrzeganie specyfiki kulturowej Cieszyna

\begin{tabular}{|c|c|c|c|}
\hline \multirow{2}{*}{$\begin{array}{c}\text { Dostrzeganie specyfiki kulturowej } \\
\text { Cieszyna }\end{array}$} & \multicolumn{3}{|c|}{$\begin{array}{l}\text { Kompetencje językowe respondentów [\%] } \\
\qquad(N=124)\end{array}$} \\
\hline & niskie & średnie & wysokie \\
\hline Różnorodność kulturowa & 3,3 & 21,3 & 37,4 \\
\hline Działalność organizacyjna & 35,0 & 45,7 & 43,3 \\
\hline Czynniki subiektywne & 39,8 & 23,6 & 14,3 \\
\hline Cechy przestrzenne & 21,9 & 9,4 & 5,0 \\
\hline Ogółem & 100,0 & 100,0 & 100,0 \\
\hline
\end{tabular}

Źródło: badania własne.

Tabela 12

Kompetencje językowe a stosunek do różnorodności

\begin{tabular}{|c|c|c|c|}
\hline \multirow{2}{*}{ Typy tolerancji } & \multicolumn{3}{|c|}{$\begin{array}{l}\text { Kompetencje językowe respondentów [\%] } \\
\qquad(N=224)\end{array}$} \\
\hline & niskie & średnie & wysokie \\
\hline Empatyczna & 15,5 & 42,8 & 53,1 \\
\hline Konformistyczna & 25,3 & 17,2 & 14,4 \\
\hline Aktywna & 29,7 & 25,0 & 17,2 \\
\hline Pasywna & 29,5 & 15,0 & 15,3 \\
\hline Ogółem & 100,0 & 100,0 & 100,0 \\
\hline
\end{tabular}

Źródło: badania własne.

Tabela 13

Kompetencje kulturowe a dostrzeganie specyfiki kulturowej Cieszyna

\begin{tabular}{|c|c|c|c|}
\hline \multirow[t]{2}{*}{$\begin{array}{c}\text { Dostrzeganie specyfiki kulturowej } \\
\text { Cieszyna }\end{array}$} & \multicolumn{3}{|c|}{$\begin{array}{c}\text { Kompetencje kulturowe respondentów (wymiar dotyczący wartości) } \\
{[\%]} \\
(N=124)\end{array}$} \\
\hline & niskie & średnie & wysokie \\
\hline Różnorodność kulturowa & 5,3 & 43,7 & 44,5 \\
\hline Działalność organizacyjna & 32,0 & 21,3 & 37,4 \\
\hline Czynniki subiektywne & 37,8 & 23,5 & 14,3 \\
\hline Cechy przestrzenne & 24,9 & 11,5 & 3,8 \\
\hline Ogółem & 100,0 & 100,0 & 100,0 \\
\hline
\end{tabular}

Źródło: badania własne 
Kompetencje kulturowe a stosunek do różnorodności

\begin{tabular}{|c|c|c|c|}
\hline \multirow[t]{2}{*}{ Typy tolerancji } & \multicolumn{3}{|c|}{$\begin{array}{l}\text { Kompetencje kulturowe respondentów (wymiar dotyczący wartości) } \\
{[\%]} \\
(N=181)\end{array}$} \\
\hline & niskie & średnie & wysokie \\
\hline Empatyczna & 15,5 & 53,1 & 47,8 \\
\hline Konformistyczna & 25,3 & 17,2 & 19,4 \\
\hline Aktywna & 29,7 & 19,7 & 17,6 \\
\hline Pasywna & 29,5 & 10,0 & 15,2 \\
\hline Ogółem & 100,0 & 100,0 & 100,0 \\
\hline
\end{tabular}

Źródło: badania własne

Członkostwo i zaangażowanie w organizacjach społecznych czy przynależność religijna miały pośredni wpływ na postawy tolerancyjne. Natomiast zaobserwowano kształtującą postawy tolerancyjne bezpośrednią zależność od miejsca pochodzenia oraz kompetencji kulturowych, w tym językowych, oraz od świadomości różnorodności i postaw tolerancyjnych. Za pochodzeniem ze Śląska Cieszyńskiego kryje się dylemat codziennego kontaktu z ludźmi myślącymi i zachowującymi się odmiennie. Należy więc przypuszczać, że na ów dylemat miały wpływ różnorodność kulturowa wynikająca z przynależności religijnej, narodowej, etnicznej z równoczesnym wystąpieniem świadomości bytowania w środowisku zróżnicowanym, w którym kompetencje kulturowe i językowe ułatwiały codzienne życie. Wyjaśniając ten fenomen, można nawiązać do dwóch typów reakcji ludzi na uczestnictwo w różnorodnych systemach kulturowych według Floriana Znanieckiego, który twierdzi, że negatywne emocje w stosunku do obcych wynikają z niskiej świadomości zależnej od edukacji kulturowej (Znaniecki, 1974, s. 350-352). Osoby reagujące negatywnie na odmienność zazwyczaj wychowywały się w takim środowisku, w którym były uczone tego, że istnieją tylko konkretne, możliwe do zaakceptowania wartości i normy postępowania. Socjalizacja tego typu powoduje, że jednostki w kontaktach z innymi systemami kulturowymi wykazują niechęć i negatywnie je oceniają, ponieważ nie są w stanie zmienić postawy, której nauczono je w dzieciństwie, a polegającej na tym, że pozytywne nastawienie obowiązuje tylko w stosunku do osób reprezentujących „własną grupę”, natomiast „grupy obce” stanowią zagrożenie i należy się od nich dystansować. Osoby reagujące pozytywnie na różnorodność kulturową są świadome tego, iż ich konkretny świat wartości i norm, w którym zostały wychowywane, jest tylko jakąś częścią obiektywnej kultury (cywilizacji), nadrzędnej wobec kultury lokalnej. Wydaje się, że to wychowanie, czyli socjalizacja wraz z systemem edukacyjnym, wpływa i kształtuje kompetencje kulturowe i językowe, wiążące się również z ogólną humanistyczną wrażliwością, czy nawet właśnie patrzeniem na świat ze współczynnikiem humanistycznym, który powinien być nie tylko dyrektywą badawczą, ale również podstawową kompetencją jednostki żyjącej w społecznościach różnicowanych. 


\section{Zakończenie}

W artykule o sympatiach i antypatiach mieszkańców pogranicza polsko-czeskiego Halina Rusek i Andrzej Kasperek wykazali na podstawie przeprowadzonych badań statystycznych, że relacje sąsiedzkie układają się dobrze, gdyż obie strony postrzegają siebie w pozytywnym świetle (Rusek, Kasperek, 2012, s. 97-129). Potwierdzałoby to tezę o wpływie kapitału kulturowego, jakim dysponują mieszkańcy pogranicza, na postawy tolerancyjne. Inny problem badawczy związany z tolerancją podjął Tomasz Michał Korczyński, który obserwował religijność w związku ze stereotypami w kręgu młodzieży licealnej i studentów w Warszawie i sąsiednich województwach (Korczyński, 2017, s. 29-44). Stwierdził on, że „Interesujący nas czynnik religijności lub jej braku nie odgrywa zasadniczej roli w kreowaniu negatywnego nastawienia do Niemców. W poszukiwaniu relacji między religijnością/niereligijnością a indeksem uprzedzeń wobec Niemców nie stwierdzono w przypadku licealistów, jak również studentów, zarówno religijnych, jak i niereligijnych — istotności statystycznych" (Korczyński, 2017, s. 31). Wniosek ten potwierdza tezę zawartą w niniejszym artykule, że religijność nie jest bezpośrednim czynnikiem decydującym o tolerancyjności lub jej braku w stosunku do najogólniej pojętych obcych.

Z opozycją my —oni wiąże się kategoria stereotypu, która nie była przedmiotem zainteresowania $\mathrm{w}$ tym artykule, ale $\mathrm{z}$ pewnością stereotypy wpływają negatywnie na postrzeganie obcego, co zostało odnotowane przez Zbigniewa Bokszańskiegoo w kontekście wpływu „tożsamości grupy na konstruowanie stereotypów oraz systematyzowania sposobów konceptualizowania więzi między tożsamością a obrazami innych wytwarzanymi przez tę grupę" (Bokszański, 1999, s. 37). Ten problem nie podejmowano w artykule, gdyż skupiono się na roli kapitału kulturowego i społecznego w budowaniu tolerancji.

\section{Bibliografia}

Bernstein B., 1980: Socjolingwistyka a spoleczne problemy kształcenia. W: Jezzyk i społeczeństwo. Red. M. Głowiński. Przeł. J. Arnold et al. Warszawa: Czytelnik, s. 83-119. Bokszański Z., 1999: Tożsamość kolektywna a stereotypy. „Acta Universitatis Lodziensis Folia Sociologica", nr 28, s. 25-33.

Bourdieu P., 2005: Dystynkcja. Społeczna krytyka władzy sqdzenia. Przeł. P. Biłos. Warszawa: Wydawnictwo Naukowe Scholar.

Dyczek B., 2005: Pamięć historyczna a elementy tożsamości oraz niektóre aspekty kapitatu kulturowego i społecznego młodzieży z Cieszyna i Czeskiego Cieszyna. W: Forum Socjologiczne. Pamięć a przestrzeń. Red. P. Czajkowski, B. Pabjan, M. Zuber. Wroclaw: Wydawnictwo Uniwersytetu Wrocławskiego, s. 258-297. 
Dyczek B., 2020: Kapitał kulturowy i społeczny młodzieży na Śląsu Cieszyńskim. Wrocław: Wydawnictwo Chronicon.

Greń J., 1974: Statystyka matematyczna. Modele i zadania. Warszawa: Wydawnictwo Naukowe PWN.

Holt D.B., 1998: Does Cultural Capital Structure American Consumption? "The Journal of Consumer Research", Vol. 25, No. 1, s. 1-25.

Korczyński T.M., 2017: Religijność a stereotypy narodowe. Analiza socjologiczna badań polskiej młodzieży w paradygmacie fenomenologicznej socjologii wiedzy. "Journal of Modern Science", Vol. 32(1), s. 29-44.

Kurcz Z., 2010: Socjologia pogranicza i człowiek pogranicza w świetle polskich doświadczeń. W: Okolice socjologicznej tożsamości. Red. Z. Kurcz, I. Taranowicz. Wrocław: Wydawnictwo Uniwersytetu Wrocławskiego, s. 283-301.

Lewowicki T. et al., red., 2002: Kwestie wyznaniowe w społecznościach wielokulturowych Cieszyn: Uniwersytet Śląski Filia w Cieszynie.

Lewowicki T. et al., red., 2003: Świat wartości i edukacja międzykulturowa. Red. T. Lewowicki et al. Cieszyn-Warszawa: Uniwersytet Śląski Filia w Cieszynie, Wyższa Szkoła Pedagogiczna ZNP.

Lewowicki T. et al., red., 2008: Socjalizacja i kształtowanie się tożsamości - problemy i sugestie rozwiazań. Toruń: Wydawnictwo Adam Marszałek.

Lewowicki T., Ogrodzka-Mazur E., Urban J., red., 2009: Społeczne uwarunkowania edukacji międzykulturowej. T. 1: Konteksty teoretyczne. Warszawa-Cieszyn-Toruń: Wydawnictwo Adam Marszałek.

Putnam R.D., 2008: Samotna gra w kręgle. Upadek i odrodzenie wspólnot lokalnych w Stanach Zjednoczonych. Przeł. P. Sadura, S. Szymański. Warszawa: Wydawnictwa Akademickie i Profesjonalne.

Różańska A., 2010: Dynamika poczucia tożsamości religijnej młodzieży na pograniczu polsko-czeskim i jej edukacyjne uwarunkowania. W: Dziedzictwo kulturowe jako klucz do tożsamości pogranicza polsko-czeskiego. Red. H. Rusek, A. Pieńczak, J. Szczyrbowski. Cieszyn-Katowice-Brno: Offsetdruk i media, s. 248-263.

Rusek H., 2003: Tożsamość pogranicza. Wprowadzenie. W: Pogranicza kulturowe i etniczne w Polsce. Red. Z. Kłodnicki, H. Rusek. „Archiwum Etnograficzne”. T. 41. Wrocław: Polskie Towarzystwo Ludoznawcze, Uniwersytet Wrocławski, s. 7-10.

Rusek H., Kasperek A., 2012: Sympatie i antypatie polsko-czeskie w świetle badań nad antagonizmem i pojednaniem polsko-czeskim na Ślasku Cieszyńskim. W: TRANSCARPATHICA Prace EuroInstytutu Polsko-Czesko-Stowackiego, T. 1: Pogranicze - Sasiedztwo - Stereotypy. Przypadek polsko-czeskich relacji wraz z francusko-niemieckim casestudy. Red. A. Kasperek. Cieszyn-Katowice: Interfon, s. 97-129.

Rusek H., Pieńczak A., Szczyrbowski J., red., 2010: Dziedzictwo kulturowe jako klucz do tożsamości pogranicza polsko-czeskiego. Cieszyn—Katowice-Brno: Offsetdruk i media.

Świątkiewicz W., 1993: Rola religijności w procesach legitymizacji społecznego świata. W: Społeczny świat i jego legitymizacje. Red. Idem. Katowice: Wydawnictwo Uniwersytetu Śląskiego, s. 25-43.

Znaniecki F., 1974: Ludzie teraźniejsi a cywilizacja przyszłości. Warszawa: Wydawnictwo Naukowe PWN. 